\title{
8 Year Old Jehovah's Witness with History of Ruptured Cerebral Arteriovenous Malformation, Complicated by New Intranidal Aneurysm
}

\author{
Romerson Dimla and Ellen Park* \\ Department of Anesthesiology, University of Southern California, USA
}

Submission: November 17, 2017; Published: March 19, 2018

*Corresponding author: Ellen Park, MD, Department of Anesthesiology, University of Southern California, USA, Email: Ellen.Park@med.usc.edu

Goals

a) Explain the legality of transfusing a Jehovah's Witness minor

b) Summarize the perioperative management of pediatric AVM resection

c) Review the importance of following up AVMs

\section{Introduction}

8 year old Jehovah's Witness female with a history of ruptured frontal arteriovenous malformation s/p bi-frontal craniotomy for clip ligation and embolization in 2015, was in her usual state of health until she developed a severe frontal headache, emesis, and altered mental status. MR angiography revealed a new 3.3 x 4.3 x $3.0 \mathrm{~cm}$ intranidal aneurysm with an underlying intraparenchymal hematoma (Figure 1). The decision was made to perform an AVM resection [1-3].

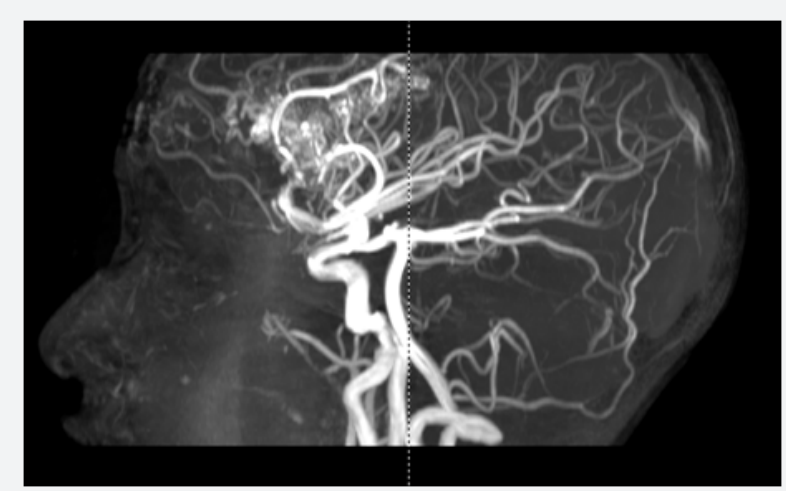

Figure 1: MRA.

\section{Intra-op course}

Rapid sequence induction was performed with fentanyl (1mcg/kg), propofol (2mg/kg), and succinylcholine (2mg/ $\mathrm{kg}$ ) and intubation with a $6 \mathrm{~mm}$ cuffed endotracheal tube. Standard monitors along with a $22 \mathrm{G}$ left radial arterial line was placed. IV access with a right femoral 5Fr triple lumen catheter. Maintenance with propofol $(100-200 \mathrm{mcg} / \mathrm{kg} / \mathrm{min})$ and remifentanil $(0.1-0.3 \mathrm{mcg} / \mathrm{kg} / \mathrm{min})$ infusions for monitoring of SSEPs and MEPs. Fosphenytoin (500mg) for seizure prophylaxis, and brain relaxation with hyperventilation, mannitol $(0.5 \mathrm{mg} /$ $\mathrm{kg}$ ), dexamethasone (20mg), and lasix (5mg). Surgeon requested SBP $<100$ with boluses of propofol. Cerebral perfusion pressure maintained with dopamine $(2-5 \mathrm{mcg} / \mathrm{kg} / \mathrm{min})$ and phenylephrine $(10-20 \mathrm{mcg} / \mathrm{min})$ infusions during burst suppression. After ongoing bleeding led to hemodynamic instability, a mutual decision was made with the surgery team to transfuse. In total, the patient received $500 \mathrm{ml}$ of crystalloid, $1 \mathrm{~L}$ of albumin, $500 \mathrm{ml}$ of Cell Saver, and $272 \mathrm{ml}$ of packed red blood cells. Estimated blood loss was $800 \mathrm{ml}$. She remained intubated and transferred to the PICU, extubated on POD 1, and had an uneventful recovery (Figure 2) [4].

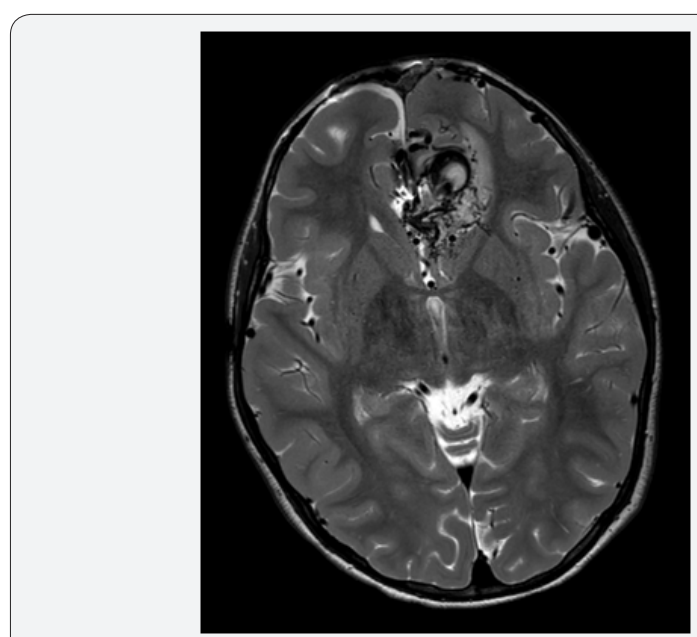

Figure 2: MRI of brain.

\section{Discussion}

The incidence of cerebral AVMs in the U.S. range from 0.14$0.5 \%$ of the population, with children making up $3 \%$. Associated aneurysms range from $3.7 \%-8.7 \%$, and recurrence occurs in $2.6 \%$ 
of patients. Although rare, vigilance must be exercised to rule out a fatal complication in the work up of altered mental status. There is no clear consensus on CPP or systolic blood pressure range to maintain in a child. Fortunately, keeping blood pressures within $20 \%$ of baseline resulted in no neurologic deficits.

Blood transfusions, even in a life threatening situation, were declined by the parents. Ideally, an official court mandated order would be obtained to transfuse a JW minor, but this was not possible due to urgency of the case. Under California Business \& Professions Code 2397, physicians are protected in emergency treatment for minors. An emergency is "a situation requiring immediate services for alleviation of severe pain or immediate diagnosis of unforeseeable medical conditions, which, if not immediately diagnosed and treated, would lead to serious disability or death" [5].

\section{References}

1. Abd Elsayed A, Wehby AS, Faraq E (2014) Anesthetic management of patients with intracranial aneurysms. Ochsner J 14(3): 418-425.

2. Allen B, Chiu YL, Gerber LM, Ghajar J, Greenfield JP (2014) Age specific cerebral perfusion pressure thresholds and survival in children and adolescents with severe traumatic brain injury. Pediatr Crit Care Med 15(1): 62-70.

3. Brezina P, Moskop JC (2007) Urgent medical decision making regarding a jehovah's witness minor: a case report and discussion. N C Med J 68(5): 312-316.

4. El Ghanem M, Kass HT, Kass HO, Alderazi YJ, Amuluru K et al. (2016) Arteriovenous malformations in the pediatric population: review of the existing literature. Interv Neurol 5(3-4): 218-225.

5. (2014) California minor consent and confidentiality law. National Center for Youth Law.

\section{Your next submission with Juniper Publishers} will reach you the below assets

- Quality Editorial service

- Swift Peer Review

- Reprints availability

- E-prints Service

- Manuscript Podcast for convenient understanding

- Global attainment for your research

- Manuscript accessibility in different formats ( Pdf, E-pub, Full Text, Audio)

- Unceasing customer service

Track the below URL for one-step submission https://juniperpublishers.com/online-submission.php 